\title{
Organic Tuber Potato Production by Aerobic Compost Tea, Beneficial Microbes, Chicken Manure and Plant Compost
}

\author{
Abou El-Goud, Amal K. ${ }^{1 *}$ and Mona M. Yousry ${ }^{2}$ \\ ${ }^{1}$ Department of Botany, Organic Agriculture, Faculty of Agriculture, Damietta University, Egypt. \\ ${ }^{2}$ Department of Plant Production, Vegetable, Faculty of Agriculture, Saba Basha, Alexandria University, Egypt.
}

\begin{abstract}
Two field experiments were conducted at Agricultural Faculty (Saba-Basha) Alexandria University, in order to study the effect of Aerobic Compost tea (ACT), Beneficial microbes (BM), Chicken manure (CHM) and plant compost (PC) on yield and quality of potato (cv. Bamba). This study was carried out with randomized complete block design with three replicates. Efficiency of twelve treatments on yield and nutrient contents of shoots and tubers were determined. Results shown that (the mixture of CHM. and PC) with ACT or BM only or together them lead to significant increases of vegetative characters and nutritional status in leaves and tubers. Controlled plant gave the lowest mean values of the given characters. Treatments contained ACT, BM., PC and CHM significantly increased in all morphological characteristics and qualities of tuber potato. The mixture of CHM. and PC with ACT or BM only were caused the significantly increases in mineral contents, sugar, starch and T.S.S. \% of tubers compared with controlled plant $\left(\mathrm{T}_{12}\right)$. The highest values of total yield were achieved by (the mixture of $\mathrm{BM}+75 \% \mathrm{CHM} .+25 \% \mathrm{PC}=\mathrm{T}_{5}$ ) compared to $\mathrm{T}_{12}$. The use of $T_{5}$ was also increased mean values of the No. of tubers/plant and tuber weight significantly compared to $T_{12}$. This study demonstrated that ACT, BM., CHM and PC utilization to stimulate naturally occurring populations, organic potato production development and prevent the environmental pollution.
\end{abstract}

Keywords: Aerobic Compost tea; Beneficial microbes; Chicken manure; Plant compost; Potato tubers.

\section{Introduction}

Potato (Solanum tuberosum L.) is one of the most important vegetables in Egypt. It gained a considerable importance as an export crop to European markets and one of the national income resources. however, its production faces some challenges related to soil-borne diseases, marketable yield and quality, sugars and dry matter content of the produced tubers, tuber content in terms of nitrate, minerals, vitamins, bioactive compounds, and antioxidants, and consumer appreciation regarding the sensory characteristics of tubers and processed products (Djaman et al., 2021). Potatoes require high amounts of nitrogen, potassium and phosphorus

\footnotetext{
*Corresponding author Amal K. Abou El-Goud, Email: amalgoud08@gmail.com

Received: September 30, 2021; Accepted: November 21, 2021; Published online: November 21, 2021.

(C)Published by South Valley University.

This is an open access article licensed under $@()(2)$
}

fertilizers for optimum growth, production and tuber quality. Nutrition analysis showed that potato is a healthy food in terms of vitamins, minerals, proteins, essential amino acids and carbohydrates (Andre et al., 2007). Potato is the fourth important food in the world ranking at 365.8 million tons per year (FAOSTAT, 2014).

Aerobic compost tea (ACT) in modern terminology, is a compost extract brewed with a microbial food source molasses, kelp, rock dust, humic and fulvic acids. The compost tea brewing technique, an aerobic process, extracts and grows populations of beneficial micro-organisms (Mengesha et al., 2017). Compost tea was used as the source of organic substances. As so in recent years, compost tea has emerged as an important component of the integrated nutrients supply system and hold a great promise to improve crop yields through environmentally better nutrient 
supplies. Extracts of the finished composts were reduced bacterial toxicity Ana et al. (2021). Compost tea is a highly concentrated microbial solution produced by extracting beneficial microbes from vermi-compost and /or compost. It is a source of foliar and organic nutrients, contains chelated micronutrients for easy plant absorption and the nutrients for both plant and microbial uptake. The most widely described benefit of compost tea is their ability to decrease plant disease when used as soil drenches or foliar sprays (Scheuerell and Mahaffee, 2004; Kandil et al., 2011; Philip et al., 2011).

Beneficial microbes (BM) are the microorganisms and their products which are utilized to increase soil fertility. Biofertilizers are products containing living cells of different types of microorganisms, when applied to seeds, plant surface and rhizosphere to colonize around the plant that promotes growth by converting nutritionally important elements (Robert et al., 2012; Marta et al., 2021). They able to dissolve the macro and micro nutrients by their different organic acids produced, converted from unavailable to available through biological process such as nitrogen fixation and solubilization (Rokhzadi et al., 2004; Philip et al., 2011; Mengesha et al., 2017). El Yazid et al. (2007) found that beneficial microorganisms as biofertilizers accelerate and improve the plant growth and protect them from pests and diseases. Soil microbial activities are major factors that determine the availability of nutrients to plants, consequently they have significant influences on plant health and productivity (Jeffries et al., 2003; El-Tantawy et $a l ., 2009)$. Beneficial microbes get benefit to crops, such as potato crop (Mengesha et al., 2017; Abou El Goud, 2020 a, b, c; Djaman et al., 2021).

Chicken manure plays an important role in potato production under sandy soil conditions. Organic fertilizers improve soil structure, which encourage the plant to have good roots and improving aeration in the soil. Many studies investigated the effect of organic fertilizers on potato production. In Egypt chicken manure is usually used as organic fertilizer. Generally, soil organic matter is considered as an important factor for improving physical, chemical and biological properties of the soil (Abdel Moez et al., 1999; ElTantawy et al., 2009; Abou El-Goud et al., 2020).

Plant Compost able to modify the physical, chemical and biological soil properties in the root zone can be repaired by adding compost as a fertilizer (Mandic et al., 2011; Setiyo et al., 2016; Mona and Abou El-Goud. 2020). Soil acidity or $\mathrm{pH}$, content of macro and micro nutrients, and CEC are the chemical properties of soil which can improve with compost (Ibrahim, 2018; Djaman et al., 2021). Fertilization with compost improves the soil biological properties by multiplying beneficial microbes' population.

Organic farming systems are based on three practical pillars; 1- Improving and increase the soil fertility by using organic fertilizers; 2 - the deletion of synthetic fertilizers and synthetic pesticides and the lower use of high energy consuming feedstuff (FlieBbach, et al., 2006; El-Wehedy, 2008; Djaman et al., 2021); 3- High application of bio and organic fertilizers are necessary not only to maintain soil fertility, increased the crop quality and yield but also to prevent the environmental pollution.

The objectives of this study are to focus on the effect of aerobic compost tea, beneficial microbes, chicken manure and plant compost on the growth, yield and chemical composition of potato tubers (cv. Bamba) along with avoiding the environmental pollution from chemical fertilizers usage which lead to bad effects on potential health of plants, animals and humans.

\section{Materials and methods}

\subsection{Experimental location and arrangement}

Two field experiments were conducted at the Faculty of Agriculture (Saba-Basha), Alexandria University; during the fall seasons on $20^{\text {th }}$ and $23^{\text {rd }}$ of September of seasons 2017 and 2018 respectively, to study the response of potato plants cv. Bamba to different organic and biofertilizers such as Aerobic Compost tea, Beneficial microbes, Chicken manure and plant compost under drip irrigation system. A surface soil sample $(0-30 \mathrm{~cm})$ was collected before planting to identify some physical and chemicals properties $[\mathrm{pH}=7.8$, E.C. 
$(1: 1$ water extract $)=0.44 \mathrm{dS} / \mathrm{m} ;$ O.M. $\%=0.30 \%$, available of $\mathrm{N}=116.3 \mathrm{mg} / \mathrm{kg}, \mathrm{P}=21.0 \mathrm{mg} / \mathrm{kg}$ and $\mathrm{K}=430 \mathrm{~m} \mathrm{~g} / \mathrm{kg}$ and $\left.\mathrm{CaCO}_{3} \%=32 \%\right]$. The texture of soil was sand $(55.9 \%)$, clay $(23.7 \%)$ and loam silt $(20.4 \%)$. As well as, physico-chemical properties of the applied organic fertilizers as (chicken manure and plant compost) samples were taken and analyzed before adding to the soil to determine (total organic matter\%= 29.21 and $31.06 \%$, organic carbon $\%=14.23$ and $16.38 \%$, $\mathrm{C} / \mathrm{N}$ ratio= $1: 5.7$ and 1:9.6, $\mathrm{pH}=7.3$ and 7.9, E.C. $=2.3$ and $1.97 \mathrm{dS} / \mathrm{m}$, total amount of $\mathrm{N}=2.5$ and $1.7 \%, \mathrm{P}=3.23$ and $2.7 \%$ and $\mathrm{K}=3.9$ and $2.4 \%$ ) , respectively during the two seasons according to Page et al., 1982; Chapman and Pratt, 1978 and Lowther, 1980 .

\subsection{Experimental materials and design}

\subsubsection{B.M. (Beneficial microbes)}

consist of Azotobacter as a source of $(\mathrm{N})+$ Bacillus megatherium as a source of $(\mathrm{P})+$ Bacillus circulans as a source of $(\mathrm{K})$. Beneficial microbes were obtained from Cairo MIRCEN- Fac. Agric., Ain Shams Univ., Cairo Egypt. It was added at dose of $7 \mathrm{ml} /$ hill during planting of potato tubers.

\subsubsection{ACT (Aerobic Compost Tea)}

according to (Ingham 2000; Mengesha et al., 2017; Abou El Goud, 2020a), it was added as it soil drench $(150 \mathrm{ml} / \mathrm{hill})$. It was prepared to from500 $\mathrm{g}$ plan compost, $50 \mathrm{~g}$ humic maize meals), then left them $72 \mathrm{hr}$, for brewing cycle. After that, mixed $2 \mathrm{~L}$ of aerobic compost tea $+2 \mathrm{~L}$ of tap water (1:1) concentration.

\subsubsection{Chicken manure (CHM.)}

was added at two doses; $\mathrm{R}_{75 \%}(2 \mathrm{Kg} / \mathrm{plot})$ and $\mathrm{R}_{25 \%}(0.7 \mathrm{Kg} / \mathrm{plot})$, that calculated and attributed to the recommended dose of chicken manure is $\mathrm{R}_{100 \%}$ $=3.5$ tons $/$ fed.

\subsubsection{Plant Compost (PC)}

from plant residues was added at two doses; $\mathrm{R}_{75 \%}$ (3.4 Kg / plot) and $\mathrm{R}_{25 \%}(1.1 \mathrm{Kg} / \mathrm{plot})$, that calculated and attributed to the recommended dose of compost is $\mathrm{R}_{100 \%}=6$ tons /fed. Total amount of plant compost and chicken manure for each treatment were applied prior to the soil about 25 days before planting on $24^{\text {th }}$ of August at two seasons 2017 and 2018. Treatments were carried out in this investigation as follow;

$\mathrm{T}_{1}$ - B.M.

$\mathrm{T}_{2}-\mathrm{ACT}$

$\mathrm{T}_{3}-75 \% \mathrm{CHM}+25 \% \mathrm{PC}$

$\mathrm{T}_{4}-25 \% \mathrm{CHM}+75 \% \mathrm{PC}$

$\mathrm{T}_{5}-$ B.M. $+75 \% \mathrm{CHM}+25 \% \mathrm{PC}$

$\mathrm{T}_{6}-$ B.M. $+25 \% \mathrm{CHM}+75 \% \mathrm{PC}$

$\mathrm{T}_{7}-\mathrm{B} . \mathrm{M} .+\mathrm{ACT}$

$\mathrm{T}_{8}-\mathrm{ACT}+75 \% \mathrm{CHM}+25 \% \mathrm{PC}$

$\mathrm{T}_{9}-\mathrm{ACT}+25 \% \mathrm{CHM}+75 \% \mathrm{PC}$

$\mathrm{T}_{10}-\mathrm{ACT}+\mathrm{B} \cdot \mathrm{M} .+75 \% \mathrm{CHM}+25 \% \mathrm{PC}$

$\mathrm{T}_{11}-\mathrm{ACT}+\mathrm{B} . \mathrm{M} .+25 \% \mathrm{CHM}+75 \% \mathrm{PC}$

$\mathrm{T}_{12}$ - Control NPK (recommended doses of chemical fertilizer $\mathrm{N}, \mathrm{P}$ and $\mathrm{K}$ of Ammonium nitrate $33.5 \%=500 \mathrm{~kg} / \mathrm{fed} .+$ Super phosphate $15.5 \%=500 \mathrm{~kg} / \mathrm{fed}$. + Potassium sulphate $48 \%=75$ $\mathrm{kg} / \mathrm{fed})$. Two field experiments were carried out in a complete randomized blocks design with 3 replications (RCBD). Total plot area was $(3.5 \mathrm{~m}$ length $\times 0.80 \mathrm{~m}$ width $=2.8 \mathrm{~m}^{2}$ ) and the distance between two hills was $30 \mathrm{~cm}$, seven plants per plot. Weeds were controlled by hand howling once a week after planting.

\subsubsection{Organic protection}

there were organic pesticides programme by using neem oil extraction as a foliar application on leaves $(4 \mathrm{ml} / \mathrm{L})$ every 20 days after 50 days from planting to increase the plant defense against the pathogen and cover with net to protect the potato plants from insect (Emmanuel and Maerere, 2018).

\subsubsection{Vegetative growth characters}

Six plant samples per plot were randomly selected at 100 days after planting for (cv. Bamba) for the determination of the following growth parameters: plant height $(\mathrm{cm})$, No. of leaves/ plant, No. branches/plant. Plant dry weight (g/plant) was determined by drying the fresh material at $70^{\circ} \mathrm{C}$ for $48 \mathrm{~h}$, then the weight fixing. Leaf chlorophyll 
indication (SPAD) for determination chlorophyll readings at harvest, greenness was done using a non- destructive method using a SPAD 502 chlorophyll meter for each plant, 3 recently fullexpanded leaves were randomly chosen for SPAD (Soil Plant Analysis Development), measurement at the average of 3 readings were recorded (Yadava, 1985; Marquard and Tipton,1987).

\subsection{Yield and yield component parameters}

No. of tubers/plant which counted as the average number of tubers per plot. Average tuber weight (kg/plant): whereas the weight and number of tubers /plot were assessed, then the total weight was divided by the total number. Total tuber yield (ton/fed) was calculated in the harvesting time of cultivar (cv. Bamba) at $30^{\text {th }}$ of December in both seasons, then calculated and attributed to the feddan (feddan $=4000 \mathrm{~m}^{2}$ ). Tuber quality characters such as; total sugars (\%) were determined calorimetrically using phenol and Sulphur acid according to Malik and Singh, 1980. The percentage of starch was determined using a sample of $0.1 \mathrm{~g}$ of the residue by hydrolysis with concentrated HCL for $3 \mathrm{~h}$ under reflux condenser (AOAC,1985). Total soluble solids of tubers (TSS\%) were determined in the tuber juice as percentage by hand refractometer according to Chen and Mellenthin (1981).

\subsection{Plant chemical analysis}

measurement of mineral nutrients in the leaves and tubers $\mathrm{N}, \mathrm{P}$ and $\mathrm{K}$ contents of leaves and tubers; The N, P and $\mathrm{K}$ percentages were determined in the dry leaves and tubers. Samples of leaves and potato tubers were washed by tap water then by distilled water and oven dried at $75^{\circ} \mathrm{C}$ for 3 days to fix dry weights. Dried samples of leaves and tubers were finely ground, then wet digested by using concentrate of $\mathrm{H} 2 \mathrm{SO} 4-\mathrm{H} 2 \mathrm{O} 2$ mixture according to (Lowther, 1980). The following determinations were carried out in the digested solution: Nitrogen content: was determined colorimetrically by Nessler's method (Chapman and Pratt, 1978). Phosphorus content was determined by the Vanadomolyate yellow method as given by Jackson (1967) and the intensity of color developed was read in spectrophotometer at $405 \mathrm{~nm}$. Potassium content: was determined according to the method described by Jackson (1967) using Beckman Flame photometer.

\subsection{Statistical Analysis}

Data were statistically analyzed using Costat Software (Steel and Torrie, 1980), and treatments means were compared using Duncan's Multiple Range test at $5 \%$ level of probability.

\section{RESULTS AND DISCUSSION}

The results of the soil analysis before cultivated showed that the soil which used in the experiment was sandy loam texture. The amounts of available macro and micro-elements were in the range of low availability for plant nutrition as compared to standard values (Soltanpour, 1985). The amount of available phosphorus of the soil was below $(35 \mathrm{mg} / \mathrm{kg})$ from the range of availability according to Landon (1991). This finding further signifies that the soil requires external application of nutrients for high growth and yield of the crop. Data presented from organic fertilizers analyzes indicated that, the compost tea and chicken manure which is rich in macro elements in the suitable range of the require for the plants.

\subsection{Vegetative growth characters}

The results in Table (1) demonstrated that all organic and bio-fertilizer treatments when applied on potato tubers plants significantly increased all vegetative growth characters as compared with control treatment $\left(T_{12}\right)$, in both seasons. Generally untreated plants showed the lowest significant average values for all vegetative growth characters except for plant height $\mathrm{cm}$, controlled plants gave the highest mean value as $(136.50 \mathrm{~cm})$ in the first season only. The recorded results indicated that the highest average values were obtained due to the application of $\mathrm{T}_{11} \quad$ (ACT+B.M. $+25 \% \mathrm{CHM}+75 \% \mathrm{PC})$ for plant height $(129.17 \mathrm{~cm})$ in the first season and $\mathrm{T}_{5}$ 
(B.M.+75\%CHM+25\%PC) was $(140.13 \mathrm{~cm})$. About for number of leaves/ plant, it was observed that $\mathrm{T}_{10}(\mathrm{ACT}+\mathrm{B} \cdot \mathrm{M} .+75 \% \mathrm{CHM}+25 \% \mathrm{PC})$, gave the highest mean value in the first season as (102.00) and $\mathrm{T}_{5}$ (B.M.+75\%CHM+25\%PC) was (113.33) in the second season. Regarding number of branches per plant character, $\mathrm{T}_{\mathbf{1 0}}$ gave rise the highest average value during first season was (8.00) but $\mathrm{T}_{5}$ gave the highest data recorded as (9.67) in second season. About shoot dry weight, the highest mean value was obtained from $\mathrm{T}_{5}$ (94.53 g/plant) in season 2018. The tabulated results indicated, clearly what, the bio and organic fertilizers, their modes of actions in regulating the physiological processes on growth and development of potato (cv. Bamba) under the study via using aerobic compost tea, beneficial microbes, chicken manure and plant compost application. The results obtained in this study are in agreement with other previous reports showed that certain beneficial microorganisms and aerated compost tea used in root applications, increased groups of different beneficial microorganisms which can be used for many purposes include mycoparasites (Fernandez-Luqueno et al., 2010; Larkin, et al., 2010; Mengesha et al., 2017), rhizosphere colonies (Fernandez-Luqueno et al., 2010; Larkin, et al., 2010; Djaman et al., 2021), hyperparasitic fungi (Schonbeck and Dehne, 1986; Djaman et al., 2021), epiphytic microbes (Fernandez-Luqueno et al., 2010; Larkin, et al., 2010) along with individual microbes such as Pseudomonas (Mengesha et al., 2017; Ibrahim, 2018), Azotobacter, Trichoderma and Bacillus ( $\mathrm{Pa}$ pavizas, 1985; Djaman et al., 2021). Apparently, disease suppressive microbes that have been found in compost tea and beneficial microbes are able to colonize the surface and roots of plants when applied properly. Organic manures such as chicken manure, plant compost and compost tea simply concentrate these beneficial microbes and allow the grower to concentrate form as nutrients and for resistance and diseases control (Mengesha et al., 2017 and Ibrahim, 2018; Ana et al., 2021). These are in accordance with our results which attributed to the high capacity of the plants due to the treatments in building metabolites which reflect on more vigorous plant healthy growth and major rooting surface area system which in turn contributes to increase the dissolving and translocation of macro and micro- elements concentration in root hairs for a good building of plant body health. These lead to enhance the plant growth, immunity system, plant hormones and regulators for increasing the crop yield and quality of potato tubers (Abou-Hussein, 2005; ElShazly, 2008; Ibrahim, 2018; Abou El Goud et al., 2021; Abou El Goud, 2020a; Djaman et al., 2021). Leaf chlorophyll reading (SPAD), data presented in Table (1) divulged that highest reading values of chlorophyll index were found when plants fertilized with $\mathrm{T}_{6}, \mathrm{~T}_{8}$ and $\mathrm{T}_{9}$ as $(38.40,37.73$ and 37.70 ) in the first season respectively, but $T_{5}$ (46.23) in the second season. This event may be occurred owing to the ability of organic and biofertilizers on potato leaf chlorophyll reading related to the important role of nitrogen, phosphorus and potassium in plant tissues that reflect on highly vegetative growth rates. The treatments mentioned above play vital roles in photosynthesis, carbohydrate transport, protein formation, control of ionic balance, regulation of plant stomata and water use activation of plant enzymes and other processes (El-Dissoky, 2008; El-Shazly, 2008; Shaheen et al., 2018; Ibrahim, 2018 Abou El Goud, 2020 a, b, c and Djaman et al., 2021).

\subsection{Yield and its component characters}

Table (2) expressed that application with $\mathrm{T}_{5}$ (B.M. $+75 \% \mathrm{CHM}+25 \% \mathrm{PC}$ ) affected significantly all studied characteristics of the tested potato cultivar (No. of tubers per plant, average tuber weight, total tuber yield/fed.). Whereas, the lowest significant average values for all yield characters of potato tubers were derived from control plants compared with fertilized plants with those organic and biofertlizers during both seasons. Data presented in Table (2) cleared that the highest average values for number of tubers per plant character was obtained from $\mathrm{T}_{5}$ treatment $(13.00$ and 13.33) at two seasons respectively. The average tuber weight of treatment $\mathrm{T}_{3}(75 \% \mathrm{CHM}+$ 25\% PC) brought about the highest average values $(1.500 \mathrm{~kg} / \mathrm{plant})$ during the first season and the treatment $\mathrm{T}_{5}$ gave the highest mean values 
$(1.357 \mathrm{~kg} / \mathrm{plant})$ in the second season. Regarding total yield/fed., plants treated with $\mathrm{T}_{5}$ (B.M.+75\%CHM+25\%PC) lead to the highest average values (20.74 and 23.03 tons/fed.) during both seasons regularly. These results are in agreement with (Jeyabal and Kuppuswamy, 2001; Abou El Goud, 2020 c; Djaman et al., 2021), they showed that biofertilizers can prevent the depletion of the soil organic matter. Also, (Ibrahim, 2018; Abou El Goud, 2020 and Mona and Abou ElGoud. 2020), they focused on the organic agricultural production in Egypt in order to avoid plant and environmental pollution with different elements and to reduce the usage of chemical fertilizers. Biofertilizers are products when applied to seeds, plant surface or soil, colonize the rhizosphere and promotes growth by converting nutritionally important elements (nitrogen and phosphorus) from unavailable to available form through biological process such as nitrogen fixation and solubilization of rock phosphate (Marta et al., 2021; El-Shazly, 2008; El-Tantawy et al., 2009; Ibrahim, 2018;Abou El Goud, 2020 a, b, c). Organic fertilizers are useful for plants due to their beneficial effect on the physical, chemical and biological characteristics of the soil, which in turns, influenced growth and increase plant production (Meunchang et al., 2006; Shaheen et al., 2018; Djaman et al., 2021). These results are in agreement with (Bhattacharyya and Pati, 2000 and Abou El Goud, 2020a), they found that B.M., produced high amount of IAA in root zone. (ElTantawy et al., 2009; Shaheen et al., 2018; Shoresh, 2010; Abou El Goud, 2020a; Djaman et al., 2021), they noticed that many autotrophic bacteria produce an endogenous phytohormones like auxin, cytokinens and gibberellins which enhance growth of roots, shoots and consequently plant yield. Several species of Trichoderma are reported to produce secondary metabolites with antibiotic activity and promote growth, improves crop yield, increase nutrient availability and enhance disease resistance, weight of shoots and roots and nodules number (Benetiz et al., 2004; Reino et al., 2008; Vinale et al., 2008; Abou El Goud, 2020a,b; Djaman et al., 2021). Furthermore, aerobic compost teas are considered advantageous compared with other organic wastes since they present a lower risk of toxicity due to the presence of heavy metals, pollutants, aromatic hydrocarbons, pharmaceuticals as well as viruses, fecal coliforms and salmonella (Benito et al., 2005; Moretti et al., 2015; Morales-Corts et al., 2018), and because of the interesting biological activity of ACT materials (Ros et al., 2005; Ana et al., 2021). Researchers studied the role of organic fertilizers, which were incorporated with biofertilizer, as stimulating the plant growth, total protein, nutrients uptake, tuber germination, good potato yield and quality.

\subsubsection{Tuber quality's characters}

total sugars, starch and TSS\% in potato tubers; results postulated in Table (3) revealed that all applied organic and biofertilizer treatments showed the highest significant average values of total sugars, total starch and T.S.S characters compared with control plants $\left(\mathrm{T}_{12}\right)$. Plants that fertilized with $\mathrm{T}_{9}(\mathrm{ACT}+25 \% \mathrm{CHM}+75 \% \mathrm{PC})$ lead to the highest values of the total sugars character, such as $(0.87 \%)$ in the first season and $\mathrm{T}_{5}$ as $(0.92$ $\%$ ) in the second season. As for $\mathrm{T}_{2}$ (ACT) gave the highest mean values of total starch\% as (13.90\%) in the first season and $\mathrm{T}_{5}$ as $(14.10 \%)$ in the second season. Meanwhile, $\mathrm{T}_{8}$ $(\mathrm{ACT}+75 \% \mathrm{CHM}+25 \% \quad \mathrm{PC})$ lead to the highest mean values of T.S.S.\% as $(8.33 \%)$ in the first season but $\mathrm{T}_{5}$ as $(10.17 \%)$ in the second season compared with controlled once $\left(\mathrm{T}_{12}\right)$ which gave the lowest mean values of the above mentioned characters. These are in agreement with that microbes are usually considered to play vital roles to reduce or eliminate chemical fertilizers inputs (Kandil et al., 2011; Philip et al., 2011; Larkin et al., 2012; Djaman et al., 2021). Aerobic compost tea (ACT) plays a role in the suppression of crop pests and diseases (Mengesha et al., 2017; Ibrahim, 2018; Ana et al., 2021), including pathogenic nematodes, herbivores and particularly soil-borne fungal diseases (Philip et al., 2011; Larkin et al., 2012; Mengesha et al., 2017 and Djaman et al., 2021; Abou El Goud, 2020a, b) these led to enhance total sugars, total starch and T.S.S characters in potato tubers. The effect of ACT, B.M, CHM and PC, which increasing the production of active compounds including 
enzymes, antibiotics, siderophores, and the plant hormone indole-1,3-acetic acid (Shaban et al., 2015; Abou El Goud, 2020a, b, c; Djaman et al., 2021) which lead to increase total sugars, starch and TSS\% which reflected on the potato tuber quality's characters. Also, the use of ACT in agriculture is emerging because of its ability to suppress a wide range of both soil and airborne pathogens (Martin, 2014). In this regard, compost teas are viewed as potential alternatives to the use of common synthetic fungicides in response to the increasing need for environmental sustainability of farming and food safety (Pane et al., 2012; Morales-Corts et al., 2018). The effectiveness of compost teas may vary due to differences in types of compost, management and procedures used for its preparation (Egwunatum and Lane, 2009; Pant et al., 2012). Martin (2014) indicated that the best results are obtained when aerated compost teas rather than non-aerated teas are replied, probably because dissolved oxygen supports microbial activity (Arancon et al., 2007).

\subsection{Chemical analysis of leaves and tubers characters}

\subsubsection{Potato leaves $N, P$ and $K$ contents}

Data outlined in Table (4) manifested that the highest percentages of leaves $\mathrm{N}$ concentrations were obtained when plants treated with $\mathrm{T}_{4}$ $(25 \% \mathrm{CHM}+75 \% \mathrm{PC})$ and $\mathrm{T} 5$ (B.M. $+75 \% \mathrm{CHM}+25 \% \mathrm{PC})$ as (4.47 and $4.53 \%)$ during both seasons progressively. With regard to leaves $\mathrm{P}$ content during the two seasons, nonsignificant effects were found among the treatments. However, $T_{6}$ and $T_{10}$ resulted in the highest mean values of $\mathrm{P}$ content of leaves were $(0.31 \%$ for both $)$ in the first season but $\mathrm{T}_{5}$ as $(0.31 \%)$ in the second season. The highest percentage values of $\mathrm{K}$ content in leaves were obtained from plants treated with treatments $T_{2}$, $\mathrm{T}_{6}, \mathrm{~T}_{9}, \mathrm{~T}_{10}$ and $\mathrm{T}_{11}$ during the first season as $(0.064,0.064,0.062, \quad 0.062$ and $0.061 \%$ ) respectively but $\mathrm{T}_{5}$ as $(0.065)$ in the second season. Meanwhile, control treatment recorded the lowest percentage values of $\mathrm{N}, \mathrm{P}$ and $\mathrm{K}$ contents in leaves for both seasons. The steady release of the nitrogen, phosphorus and potassium from chicken manure, ACT and B.M. may have resulted that, they have been taken up mainly in the form of available forms which probably caused nutrients accumulations in the plants tissues (Abou El Goud, 2020a, b and Djaman et al., 2021). Our results are in accordance with those reported by (Mengesha $e t$ al., 2017; Ibrahim, 2018; Abou El Goud, 2020 a, b ; Djaman et al., 2021 and Ana et al., 2021). These microbes that found in ACT and B.M stimulated the uptake of $\mathrm{N}, \mathrm{P}, \mathrm{K}, \mathrm{Mg}, \mathrm{Fe}$, and $\mathrm{Zn}$ simultaneously. Furthermore, potato yields are limited by nutrient availability in fall and early summer season (Mengesha et al., 2017; Ibrahim, 2018; Abou El Goud, 2020a, b; Djaman et al., 2021), while these microbes may benefit the yield of potato by enhancing available nutrients accumulation during the growth periods (Mengesha et al., 2017; Ibrahim, 2018; Ana et al., 2021).

\subsubsection{Potato tubers $N, P$ and $K$ contents}

Data postulated in Table (5) illustrated that the highest mean values of $\mathrm{N} \%$ in potato tubers were (3.03 and $3.23 \%$ ) when treated with $\mathrm{T}_{3}$ and $\mathrm{T}_{5}$ at two seasons respectively followed by $\mathrm{T}_{\mathbf{4}}$ and $\mathrm{T}_{\mathbf{1 1}}$ gave also, the best values in the first season as ( $2.93 \%$ for both treatments). Regarding P content in tubers, $T_{2}, T_{3}, T_{6}$ and $T_{9}$ treatments produced the highest mean values as $(0.21 \%$ for all $)$ at first season, meanwhile $\mathrm{T}_{7}$ gave the highest mean value as $(0.87 \%)$ at the second season. With regard to tubers $\mathrm{K}$ content during the first season, nonsignificant differences were found among the treatments. Moreover, $\mathrm{T}_{5}$ resulted in the highest mean values of $\mathrm{K}$ content of tubers were $(0.05$ and $0.07 \%$ ) at two seasons orderly. That is mean, organic and bio fertilizers addition may be attributed to that organic matter is a good source for plant nutritional and growth promoting substances, which able to improve the plant healthy of plant growth and vital tissues development. Similar results were reported by (ElWehedy, 2008; Mengesha et al., 2017; Ibrahim, 2018; Abou El Goud, 2020 b, c; Djaman et al., 2021), these are in agreement with the addition of bio and organic fertilizers increased the availability of soil nutrients and enhance the soil microbial propagation. Besides, the use of natural 
bio and organic materials increased the plant tissues which led to increase the nutrients in physiological and bio- chemical mechanisms in the the storage organs (Mengesha et al., 2017).

Table 1. Effect of Aerobic Compost tea (ACT), Beneficial microbes (BM), Chicken manure (CHM) and plant compost (PC) on Vegetative growth characters of potato (cv. Bamba) for both seasons 2017 and 2018.

\begin{tabular}{|c|c|c|c|c|c|c|c|c|c|}
\hline \multirow{2}{*}{$\begin{array}{ll}\text { Items } & \\
& \text { Treatments }\end{array}$} & \multicolumn{2}{|c|}{ Plant height $(\mathrm{cm})$} & \multicolumn{2}{|c|}{$\begin{array}{c}\text { No. of Leaves/ } \\
\text { Plant }\end{array}$} & \multicolumn{2}{|c|}{$\begin{array}{c}\text { No. of } \\
\text { branches/plant }\end{array}$} & \multicolumn{2}{|c|}{$\begin{array}{l}\text { Leaf chlorophyll } \\
\text { index (SPAD) }\end{array}$} & \multirow{2}{*}{$\begin{array}{c}\begin{array}{c}\text { Shoot dry } \\
\text { weight } \\
\text { (g/plant) }\end{array} \\
2018\end{array}$} \\
\hline & 2017 & 2018 & 2017 & 2018 & 2017 & 2018 & 2017 & 2018 & \\
\hline T1-B.M. & $108 \mathrm{bc}$ & $108.87 \mathrm{e}$ & $69.00 \mathrm{de}$ & $88.00 \mathrm{e}$ & $4.00 \mathrm{e}$ & $6.33 \mathrm{~d}$ & $32.83 \mathrm{ab}$ & $35.90 \mathrm{e}$ & $61.53 \mathrm{e}$ \\
\hline $\mathrm{T}_{2}-\mathrm{ACT}$ & 99.17 cde & $79.93 \mathrm{j}$ & $78.00 \mathrm{bcd}$ & $64.67 \mathrm{j}$ & $6.00 \mathrm{bc}$ & $3.33 \mathrm{~g}$ & $35.10 \mathrm{ab}$ & $26.47 \mathrm{j}$ & $35.80 \mathrm{j}$ \\
\hline $\mathrm{T}_{3}-75 \% \mathrm{CHM}+25 \% \mathrm{PC}$ & 99.17 cde & $131.33 \mathrm{~b}$ & $78.00 \mathrm{bcd}$ & $106.33 \mathrm{~b}$ & $7.00 \mathrm{ab}$ & $8.33 \mathrm{~b}$ & $36.00 \mathrm{ab}$ & $43.43 \mathrm{~b}$ & $84.73 \mathrm{~b}$ \\
\hline $\mathrm{T}_{4}-25 \% \mathrm{CHM}+75 \% \mathrm{PC}$ & $113.83 \mathrm{~b}$ & $116.13 \mathrm{~d}$ & 74.33 bcde & $94.00 \mathrm{~d}$ & $4.67 \mathrm{de}$ & $7.33 \mathrm{c}$ & $36.83 \mathrm{ab}$ & $38.03 \mathrm{~d}$ & $69.27 \mathrm{~d}$ \\
\hline T5-B.M.+75\%CHM+25\%PC & $104.27 \mathrm{bcd}$ & $140.13 \mathrm{a}$ & 74.67 bcde & $113.33 \mathrm{a}$ & $4.33 \mathrm{e}$ & $9.67 \mathrm{a}$ & $37.07 \mathrm{ab}$ & $46.23 \mathrm{a}$ & $94.53 \mathrm{a}$ \\
\hline $\mathrm{T}_{6-}-\mathrm{B} . \mathrm{M} .+25 \% \mathrm{CHM}+75 \% \mathrm{PC}$ & $94.27 \mathrm{de}$ & $102.23 \mathrm{f}$ & $79.00 \mathrm{bc}$ & $83.00 \mathrm{f}$ & 5.00 cde & $6.33 \mathrm{~d}$ & $38.40 \mathrm{a}$ & $34.20 \mathrm{f}$ & $55.50 \mathrm{f}$ \\
\hline T7-B.M.+ ACT & $99.67 \mathrm{cde}$ & $85.20 \mathrm{i}$ & $68.33 \mathrm{e}$ & $69.00 \mathrm{i}$ & $4.00 \mathrm{e}$ & $4.33 \mathrm{f}$ & $36.67 \mathrm{ab}$ & $28.20 \mathrm{i}$ & $40.47 \mathrm{i}$ \\
\hline $\mathrm{T}_{8}-\mathrm{ACT}+75 \% \mathrm{CHM}+25 \% \mathrm{PC}$ & $105.67 \mathrm{bcd}$ & $90.63 \mathrm{~h}$ & 70.33 cde & $74.33 \mathrm{~h}$ & $4.33 \mathrm{e}$ & $4.67 \mathrm{ef}$ & $37.73 \mathrm{a}$ & $30.07 \mathrm{~h}$ & $44.20 \mathrm{~h}$ \\
\hline $\mathrm{T}_{9}-\mathrm{ACT}+25 \% \mathrm{CHM}+75 \% \mathrm{PC}$ & $89.33 \mathrm{e}$ & $75.43 \mathrm{k}$ & $66.33 \mathrm{e}$ & $60.33 \mathrm{k}$ & $4.67 \mathrm{de}$ & $2.67 \mathrm{~g}$ & $37.70 \mathrm{a}$ & $24.63 \mathrm{k}$ & $33.07 \mathrm{k}$ \\
\hline $\mathrm{T}_{10-}$ & 101.33 cde & $96.13 \mathrm{~g}$ & $102.00 \mathrm{a}$ & $78.33 \mathrm{~g}$ & $8.00 \mathrm{a}$ & $5.33 \mathrm{e}$ & $35.00 \mathrm{ab}$ & $31.67 \mathrm{~g}$ & $50.17 \mathrm{~g}$ \\
\hline \multicolumn{10}{|l|}{ ACT+B.M.+75\%CHM+25\%PC } \\
\hline $\mathrm{T}_{11^{-}}$ & $129.17 \mathrm{a}$ & $121.73 \mathrm{c}$ & $82.00 \mathrm{~b}$ & $100.67 \mathrm{c}$ & $5.67 \mathrm{~cd}$ & $7.67 \mathrm{bc}$ & $31.13 \mathrm{bc}$ & $40.60 \mathrm{c}$ & $76.37 \mathrm{c}$ \\
\hline \multicolumn{10}{|l|}{ ACT+B.M.+25\%CHM+75\% PC } \\
\hline $\mathrm{T}_{12}$-Control(NPK) & $136.50 \mathrm{a}$ & 69.91 & $44.00 \mathrm{f}$ & 58.001 & $4.00 \mathrm{e}$ & $1.67 \mathrm{~h}$ & $27.10 \mathrm{c}$ & 23.101 & 29.131 \\
\hline L.S.D. 0.05 & 8.296 & 1.259 & 8.074 & 1.841 & 1.167 & 0.951 & 5.232 & 0.859 & 1.199 \\
\hline
\end{tabular}

Values with the same alphabetical letters, within a comparable group of means, don't significant differ, using L.S.D test at 0.05 level.

Table 2. Effect of Aerobic Compost tea (ACT), Beneficial microbes (BM), Chicken manure (CHM) and plant compost (PC) on yield and yield components of potato (cv. Bamba) for both seasons 2017 and 2018.

\begin{tabular}{|c|c|c|c|c|c|c|}
\hline \multirow[t]{2}{*}{ Treatments } & \multicolumn{2}{|c|}{ No. of tubers/plant } & \multicolumn{2}{|c|}{ Average Tuber weight } & \multicolumn{2}{|c|}{ Total tuber yield(ton/fed) } \\
\hline & 2017 & 2018 & 2017 & 2018 & 2017 & 2018 \\
\hline $\mathrm{T}_{1}$-B.M. & $9.67 \mathrm{bcd}$ & $8.33 \mathrm{~d}$ & $0.947 \mathrm{~d}$ & $1.077 \mathrm{e}$ & $13.85 \mathrm{~cd}$ & $18.10 \mathrm{e}$ \\
\hline $\mathrm{T}_{2}-\mathrm{ACT}$ & $7.67 \mathrm{e}$ & $3.33 \mathrm{~g}$ & $0.721 \mathrm{e}$ & $0.782 \mathrm{j}$ & $10.64 \mathrm{e}$ & $13.09 \mathrm{k}$ \\
\hline $\mathrm{T}_{3}-75 \% \mathrm{CHM}+25 \% \mathrm{PC}$ & $13.33 \mathrm{a}$ & $11.33 \mathrm{~b}$ & $1.500 \mathrm{a}$ & $1.267 \mathrm{~b}$ & $20.00 \mathrm{a}$ & $21.59 \mathrm{~b}$ \\
\hline $\mathrm{T}_{4}-25 \% \mathrm{CHM}+75 \% \mathrm{PC}$ & $11.00 \mathrm{~b}$ & $9.67 \mathrm{c}$ & $0.990 \mathrm{~d}$ & $1.145 \mathrm{~d}$ & $15.24 \mathrm{bc}$ & $19.03 \mathrm{~d}$ \\
\hline $\mathrm{T}_{5}$-B.M.+75\%CHM+25\%PC & $13.00 \mathrm{a}$ & $13.33 \mathrm{a}$ & $1.348 \mathrm{~b}$ & $1.357 \mathrm{a}$ & $20.74 \mathrm{a}$ & $23.03 \mathrm{a}$ \\
\hline $\mathrm{T}_{6}-$ B.M. $+25 \% \mathrm{CHM}+75 \% \mathrm{PC}$ & $11.00 \mathrm{~b}$ & $8.00 \mathrm{~d}$ & $0.976 \mathrm{~d}$ & $1.018 \mathrm{f}$ & $15.53 \mathrm{bc}$ & $16.86 \mathrm{f}$ \\
\hline $\mathrm{T}_{7}$-B.M.+ ACT & $8.00 \mathrm{de}$ & $4.67 \mathrm{f}$ & $0.737 \mathrm{e}$ & $0.842 \mathrm{i}$ & $11.33 \mathrm{de}$ & $13.99 \mathrm{i}$ \\
\hline $\mathrm{T}_{8}-\mathrm{ACT}+75 \% \mathrm{CHM}+25 \% \mathrm{PC}$ & 9.00 cde & $6.00 \mathrm{e}$ & $0.741 \mathrm{e}$ & $0.891 \mathrm{~h}$ & $11.41 \mathrm{de}$ & $14.89 \mathrm{~h}$ \\
\hline $\mathrm{T}_{9}-\mathrm{ACT}+25 \% \mathrm{CHM}+75 \% \mathrm{PC}$ & $7.67 \mathrm{e}$ & $2.67 \mathrm{gh}$ & $0.743 \mathrm{e}$ & $0.743 \mathrm{j}$ & $10.84 \mathrm{e}$ & $13.30 \mathrm{j}$ \\
\hline $\mathrm{T}_{10}-\mathrm{ACT}+\mathrm{B} . \mathrm{M} .+75 \% \mathrm{CHM}+25 \% \mathrm{PC}$ & $9.67 \mathrm{bcd}$ & $6.67 \mathrm{e}$ & $0.946 \mathrm{~d}$ & $0.945 \mathrm{~g}$ & $13.64 \mathrm{~cd}$ & $15.92 \mathrm{~g}$ \\
\hline $\mathrm{T}_{11}$-ACT+B.M.+25\%CHM+75\% PC & $10.33 \mathrm{bc}$ & $10.67 \mathrm{~b}$ & $1.217 \mathrm{c}$ & $1.201 \mathrm{c}$ & $16.72 \mathrm{~b}$ & $20.31 \mathrm{c}$ \\
\hline $\mathrm{T}_{12}$-Control(NPK) & $5.67 \mathrm{f}$ & $2.00 \mathrm{~h}$ & $0.406 \mathrm{f}$ & $0.498 \mathrm{k}$ & $6.25 \mathrm{f}$ & 9.011 \\
\hline L.S.D. 0.05 & 1.641 & 0.775 & 0.077 & 0.040 & 2.451 & 0.124 \\
\hline
\end{tabular}

Values with the same alphabetical letters, within a comparable group of means, don't significant differ, using L.S.D test at 0.05 level. 
Table 3. Effect of Aerobic Compost tea (ACT), Beneficial microbes (BM), Chicken manure (CHM) and plant compost (PC) on potato tubers quality characters (cv. Bamba) for both seasons 2017 and 2018.

\begin{tabular}{|c|c|c|c|c|c|c|}
\hline \multirow[t]{2}{*}{ Treatments } & \multicolumn{2}{|c|}{ Total sugar $\%$ in tubers } & \multicolumn{2}{|c|}{$\begin{array}{l}\text { Total starch \% in fresh } \\
\text { tubers }\end{array}$} & \multicolumn{2}{|c|}{ T.S.S. \% in tubers } \\
\hline & 2017 & 2018 & 2017 & 2018 & 2017 & 2018 \\
\hline $\mathrm{T}_{1}$-B.M. & $0.64 \mathrm{e}$ & $0.60 \mathrm{e}$ & $13.50 \mathrm{ab}$ & $9.17 \mathrm{e}$ & $4.00 \mathrm{c}$ & $8.50 \mathrm{~d}$ \\
\hline $\mathrm{T}_{2}-\mathrm{ACT}$ & $0.78 \mathrm{bc}$ & $0.35 \mathrm{j}$ & $13.90 \mathrm{a}$ & $5.40 \mathrm{j}$ & $5.00 \mathrm{bc}$ & $6.03 \mathrm{i}$ \\
\hline $\mathrm{T}_{3}-75 \% \mathrm{CHM}+25 \% \mathrm{PC}$ & $0.78 \mathrm{bc}$ & $0.83 \mathrm{~b}$ & $12.57 \mathrm{~b}$ & $12.50 \mathrm{~b}$ & $4.93 \mathrm{bc}$ & $9.60 \mathrm{~b}$ \\
\hline $\mathrm{T}_{4}-25 \% \mathrm{CHM}+75 \% \mathrm{PC}$ & $0.76 \mathrm{bc}$ & $0.67 \mathrm{~d}$ & $12.30 \mathrm{~b}$ & $10.13 \mathrm{~d}$ & $4.77 \mathrm{bc}$ & $8.90 \mathrm{c}$ \\
\hline $\mathrm{T}_{5}-\mathrm{B} \cdot \mathrm{M} .+75 \% \mathrm{CHM}+25 \% \mathrm{PC}$ & $0.65 \mathrm{de}$ & $0.92 \mathrm{a}$ & $12.47 \mathrm{~b}$ & $14.10 \mathrm{a}$ & $6.00 \mathrm{~b}$ & $10.17 \mathrm{a}$ \\
\hline $\mathrm{T}_{6}-$ B.M. $+25 \% \mathrm{CHM}+75 \% \mathrm{PC}$ & $0.78 \mathrm{bc}$ & $0.54 \mathrm{f}$ & $13.00 \mathrm{ab}$ & $8.40 \mathrm{f}$ & $5.60 \mathrm{bc}$ & $7.87 \mathrm{e}$ \\
\hline T 7 -B.M.+ ACT & 0.71 cde & $0.38 \mathrm{i}$ & $12.67 \mathrm{~b}$ & $6.03 \mathrm{i}$ & $5.50 \mathrm{bc}$ & $6.63 \mathrm{~h}$ \\
\hline $\mathrm{T}_{8}-\mathrm{ACT}+75 \% \mathrm{CHM}+25 \% \mathrm{PC}$ & $0.64 \mathrm{e}$ & $0.44 \mathrm{~h}$ & $13.30 \mathrm{ab}$ & $6.70 \mathrm{~h}$ & $8.33 \mathrm{a}$ & $7.10 \mathrm{~g}$ \\
\hline $\mathrm{T}_{9}-\mathrm{ACT}+25 \% \mathrm{CHM}+75 \% \mathrm{PC}$ & $0.87 \mathrm{a}$ & $0.32 \mathrm{k}$ & $12.37 \mathrm{~b}$ & $4.90 \mathrm{k}$ & $6.00 \mathrm{~b}$ & $5.27 \mathrm{j}$ \\
\hline $\mathrm{T}_{10}$-ACT+B.M.+75\%CHM+25\%PC & $0.80 \mathrm{~b}$ & $0.49 \mathrm{~g}$ & $13.00 \mathrm{ab}$ & $7.40 \mathrm{~g}$ & $5.00 \mathrm{bc}$ & $7.50 \mathrm{f}$ \\
\hline $\mathrm{T}_{11}$-ACT+B.M.+25\%CHM+75\%PC & 0.71 cde & $0.75 \mathrm{c}$ & $12.77 \mathrm{ab}$ & $11.13 \mathrm{c}$ & $5.50 \mathrm{bc}$ & $9.13 \mathrm{c}$ \\
\hline $\mathrm{T}_{12}$-Control(NPK) & $0.72 \mathrm{~cd}$ & 0.291 & $12.67 \mathrm{~b}$ & 4.171 & $4.80 \mathrm{bc}$ & $4.50 \mathrm{k}$ \\
\hline L.S.D. 0.05 & 0.066 & 0.016 & 1.067 & 0.220 & 1.542 & 0.345 \\
\hline
\end{tabular}

Values with the same alphabetical letters, within a comparable group of means, don't significant differ, using L.S.D test at 0.05 level.

Table 4. Effect of Aerobic Compost tea (ACT), Beneficial microbes (BM), Chicken manure (CHM) and plant compost (PC) on leaves nutrient contents of potato plant (cv. Bamba) for both seasons 2017 and 2018.

\begin{tabular}{|c|c|c|c|c|c|c|}
\hline \multirow[t]{2}{*}{ Treatments } & \multicolumn{2}{|c|}{$\mathrm{N} \%$ in leaves } & \multicolumn{2}{|c|}{$\mathrm{P} \%$ in leaves } & \multicolumn{2}{|c|}{$\mathrm{K} \%$ in leaves } \\
\hline & 2017 & 2018 & 2017 & 2018 & 2017 & 2018 \\
\hline $\mathrm{T}_{1}$-B.M. & $4.03 \mathrm{~d}$ & $2.93 \mathrm{e}$ & $0.29 \mathrm{abc}$ & $0.20 \mathrm{e}$ & $0.060 \mathrm{ab}$ & $0.043 \mathrm{e}$ \\
\hline $\mathrm{T}_{2}-\mathrm{ACT}$ & $4.17 \mathrm{bcd}$ & $1.67 \mathrm{j}$ & $0.27 \mathrm{~cd}$ & $0.11 \mathrm{ij}$ & $0.064 \mathrm{a}$ & $0.025 \mathrm{j}$ \\
\hline $\mathrm{T}_{3}-75 \% \mathrm{CHM}+25 \% \mathrm{PC}$ & $4.30 \mathrm{ab}$ & $4.03 \mathrm{~b}$ & $0.29 \mathrm{abc}$ & $0.27 \mathrm{~b}$ & $0.059 \mathrm{ab}$ & $0.059 \mathrm{~b}$ \\
\hline $\mathrm{T}_{4}-25 \% \mathrm{CHM}+75 \% \mathrm{PC}$ & $4.47 \mathrm{a}$ & $3.33 \mathrm{~d}$ & $0.25 \mathrm{~d}$ & $0.23 \mathrm{~d}$ & $0.059 \mathrm{ab}$ & $0.047 \mathrm{~d}$ \\
\hline $\mathrm{T}_{5}$-B.M.+75\%CHM+25\%PC & $4.20 \mathrm{bcd}$ & $4.53 \mathrm{a}$ & $0.27 \mathrm{bcd}$ & $0.31 \mathrm{a}$ & $0.058 \mathrm{ab}$ & $0.065 \mathrm{a}$ \\
\hline $\mathrm{T}_{6}-\mathrm{B} . \mathrm{M} .+25 \% \mathrm{CHM}+75 \% \mathrm{PC}$ & $4.37 \mathrm{ab}$ & $2.77 \mathrm{f}$ & $0.31 \mathrm{a}$ & $0.18 \mathrm{f}$ & $0.064 \mathrm{a}$ & $0.038 \mathrm{f}$ \\
\hline $\mathrm{T}_{7}$-B.M.+ ACT & $4.23 \mathrm{bcd}$ & $1.87 \mathrm{i}$ & $0.29 \mathrm{abc}$ & $0.12 \mathrm{i}$ & $0.060 \mathrm{ab}$ & $0.028 \mathrm{i}$ \\
\hline $\mathrm{T}_{8}-\mathrm{ACT}+75 \% \mathrm{CHM}+25 \% \mathrm{PC}$ & $4.07 \mathrm{~cd}$ & $2.17 \mathrm{~h}$ & $0.30 \mathrm{ab}$ & $0.14 \mathrm{~h}$ & $0.059 \mathrm{ab}$ & $0.031 \mathrm{~h}$ \\
\hline $\mathrm{T}_{9}-\mathrm{ACT}+25 \% \mathrm{CHM}+75 \% \mathrm{PC}$ & $4.27 \mathrm{bc}$ & $1.47 \mathrm{k}$ & $0.27 \mathrm{bcd}$ & $0.10 \mathrm{j}$ & $0.062 \mathrm{a}$ & $0.023 \mathrm{k}$ \\
\hline $\mathrm{T}_{10}-\mathrm{ACT}+\mathrm{B} \cdot \mathrm{M} .+75 \% \mathrm{CHM}+25 \% \mathrm{PC}$ & $4.07 \mathrm{~cd}$ & $2.37 \mathrm{~g}$ & $0.31 \mathrm{a}$ & $0.16 \mathrm{~g}$ & $0.062 \mathrm{a}$ & $0.035 \mathrm{~g}$ \\
\hline $\mathrm{T}_{11}-\mathrm{ACT}+\mathrm{B} \cdot \mathrm{M} .+25 \% \mathrm{CHM}+75 \% \mathrm{PC}$ & $4.23 \mathrm{bcd}$ & $3.63 \mathrm{c}$ & $0.27 \mathrm{~cd}$ & $0.26 \mathrm{c}$ & $0.061 \mathrm{a}$ & $0.053 \mathrm{c}$ \\
\hline $\mathrm{T}_{12}$-Control(NPK) & $3.17 \mathrm{e}$ & 1.071 & $0.20 \mathrm{e}$ & $0.08 \mathrm{k}$ & $0.050 \mathrm{~b}$ & 0.0201 \\
\hline L.S.D. 0.05 & 0.185 & 0.097 & 0.022 & 0.010 & 0.009 & 0.001 \\
\hline
\end{tabular}

Values with the same alphabetical letters, within a comparable group of means, don't significant differ, using L.S.D test at 0.05 level. 
Table 5. Effect of Aerobic Compost tea (ACT), Beneficial microbes (BM), Chicken manure (CHM) and plant compost (PC) on potato tubers nutrient contents (cv. Bamba) for both seasons 2017 and 2018.

\begin{tabular}{lllllll}
\hline Treatments & \multicolumn{2}{l}{$\mathrm{N} \% \mathrm{in}$ tubers } & \multicolumn{2}{l}{$\mathrm{P} \% \mathrm{in}$ tubers } & \multicolumn{2}{l}{$\mathrm{K} \%$ tubers } \\
\cline { 2 - 7 } & 2017 & 2018 & 2017 & 2018 & 2017 & 2018 \\
\hline $\mathrm{T}_{1}$-B.M. & $2.70 \mathrm{~d}$ & $2.03 \mathrm{e}$ & $0.16 \mathrm{de}$ & $0.16 \mathrm{fgh}$ & $0.04 \mathrm{ab}$ & $0.04 \mathrm{de}$ \\
$\mathrm{T}_{2}$-ACT & $3.00 \mathrm{ab}$ & $1.23 \mathrm{j}$ & $0.21 \mathrm{a}$ & $0.63 \mathrm{~b}$ & $0.04 \mathrm{ab}$ & $0.02 \mathrm{gh}$ \\
$\mathrm{T}_{3}-75 \% \mathrm{CHM}+25 \% \mathrm{PC}$ & $3.03 \mathrm{a}$ & $2.87 \mathrm{~b}$ & $0.21 \mathrm{a}$ & $0.22 \mathrm{def}$ & $0.04 \mathrm{ab}$ & $0.06 \mathrm{~b}$ \\
$\mathrm{~T}_{4}-25 \% \mathrm{CHM}+75 \% \mathrm{PC}$ & $2.93 \mathrm{abc}$ & $2.27 \mathrm{~d}$ & $0.19 \mathrm{bc}$ & $0.18 \mathrm{efg}$ & $0.04 \mathrm{ab}$ & $0.04 \mathrm{~d}$ \\
$\mathrm{~T}_{5}$-B.M.+75\%CHM+25\%PC & $2.80 \mathrm{~cd}$ & $3.23 \mathrm{a}$ & $0.19 \mathrm{bc}$ & $0.24 \mathrm{de}$ & $0.05 \mathrm{a}$ & $0.07 \mathrm{a}$ \\
$\mathrm{T}_{6}$-B.M.+25\%CHM+75\%PC & $2.83 \mathrm{bcd}$ & $1.83 \mathrm{f}$ & $0.21 \mathrm{a}$ & $0.14 \mathrm{gh}$ & $0.04 \mathrm{ab}$ & $0.03 \mathrm{e}$ \\
$\mathrm{T}_{7}$-B.M.+ACT & $2.80 \mathrm{~cd}$ & $1.37 \mathrm{i}$ & $0.19 \mathrm{bc}$ & $0.87 \mathrm{a}$ & $0.04 \mathrm{ab}$ & $0.02 \mathrm{fg}$ \\
$\mathrm{T}_{8}$-ACT+75\%CHM+25\%PC & $2.73 \mathrm{~d}$ & $1.47 \mathrm{~h}$ & $0.16 \mathrm{e}$ & $0.11 \mathrm{~h}$ & $0.04 \mathrm{ab}$ & $0.03 \mathrm{ef}$ \\
$\mathrm{T}_{9}$-ACT+25\%CHM+75\%PC & $2.83 \mathrm{bcd}$ & $1.03 \mathrm{k}$ & $0.21 \mathrm{a}$ & $0.53 \mathrm{c}$ & $0.04 \mathrm{ab}$ & $0.01 \mathrm{~h}$ \\
$\mathrm{~T}_{10}$-ACT+B.M.+75\%CHM+25\%PC & $2.80 \mathrm{~cd}$ & $1.67 \mathrm{~g}$ & $0.20 \mathrm{abc}$ & $0.13 \mathrm{gh}$ & $0.04 \mathrm{ab}$ & $0.03 \mathrm{e}$ \\
$\mathrm{T}_{11}$-ACT+B.M.+25\%CHM+75\%PC & $2.93 \mathrm{abc}$ & $2.57 \mathrm{c}$ & $0.18 \mathrm{~cd}$ & $0.19 \mathrm{efg}$ & $0.04 \mathrm{ab}$ & $0.05 \mathrm{c}$ \\
$\mathrm{T}_{12}$-Control(NPK) & $2.17 \mathrm{e}$ & $0.77 \mathrm{l}$ & $0.09 \mathrm{f}$ & $0.27 \mathrm{~d}$ & $0.03 \mathrm{~b}$ & $0.01 \mathrm{~h}$ \\
L.S.D. 0.05 & 0.165 & 0.086 & 0.018 & 0.057 & 0.009 & 0.008 \\
\hline
\end{tabular}

Values with the same alphabetical letters, within a comparable group of means, don't significant differ, using L.S.D test at 0.05 level.

\section{Conclusion and future prospects}

Beneficial microbes (B.M.), Aerobic Compost Tea (ACT), Chicken manure and plant compost are involved primarily in protection against diseases, resulting often, in improved plant growth, yield and eco-system health, the effects of beneficial microorganisms on potato cultivar (cv. Bamba). We conclude:

1. The potato tubers production require large quantities of resources (water, nitrogen, energy). Microbes in sustainable potato production systems may provide an alternative to high inputs of fertilizers.

2. Application of microbial additives to the soil must take as importance of microbial diversity especially in rhizosphere, to ensure a compatible combination, microbial community, for realistic and effective biotechnological applications, so organic and bio fertilizers appear to be the way forward.

3. Organic farming seems to be another way for yield enhancement and disease resistance in sustainable agriculture ecosystem. Currently, more attention could be paid to microbial diversity under this investigation, especially commercialization of beneficial microbes and ACT.
4. Potato tubers production require production of the organisms under commercial conditions while maintaining quality, stability, and efficiency of the products, compatibility with current application practices, cost, and safety testing (Marta et al., 2021).

5. Conducting field practical application of bio and organic fertlizers are another task which seems urgent and crucial, this will lead to improved understanding the composition of ACT, Beneficial microbial community, chicken manure and plant compost as a result, which might offer possibilities for advances in potato tubers production.

6. Following (Morales-Corts et al., 2018; Reeve et al. 2010 ; Marta et al., 2021; Ana et al., 2021; Abou El Goud et al., 2021), the potential of ACT ,Beneficial microbes and plant compost for supplementing and additives of bio and organic fertilizers to the soil are still seem promising.

\section{References}

Abdel-Moez, M.R., Saleh, A.L., Wanas, Sh.A.H. 1999. 'Influence of some organic composts on yield; nutrients uptake and consumptive use of fennel and coriander plants and some soil physical properties', J. Agric. Sci. Mansoura Univ., 24(10), pp. 6237-6253. 
Abou El-Goud, A.K. 2020 a. 'Efficiency impact of chicken manure and its tea under chemical NPK fertilizers regime on yield and quality of Molokhia (Jew, s mellow)', Arab Univ. J. Agric. Sci., Ain Shams Univ., Cairo, Egypt, 22(1), pp. 20-28. http://ajs.journals.ekb.eg

Abou El-Goud, A.K. 2020 b. 'Organic watermelon production by Smart Agritechnique using organic fertilizers, Vermitea levels and AMF in poor nutrients soil', Plant Archived, 20(2), pp. 4107- 4116. ISSN: $0972-5210$.

Abou El-Goud, A.K. 2020 c. 'Organic cowpea (Vigna unguiculatea) production by Smart Agritechnique of Organic Fertilizers Mixture" OFM" and Vermitea Levels and Beneficial Microbes "BM", J. of Plant Production, Mansoura Univ., 11(5), pp. 399 - 405. www.jpp.mans.edu.eg www.jpp.journals.ekb.eg

Abou El-Goud, A.R.; Al-Masood, Fahd, R.; Elzopy, Karam A., Yousry, M.M. 2021. 'Performance Potato Cultivars in an Organic Farming System using Organic Fertilizers, Vermicompost and Azolla', Australian J. of Crop Science, 15(07), pp. 1081-1088, ISSN: 1835-2707, ESSN, 1835-2693.

Abou-Hussein, S.D. 2005. 'Yield and quality of potato crop as affected by the application rate of potassium and compost in sandy soil', Annals Agric. Sci., Ain Shams Univ., Cairo, 50(2), pp. 573-586.

Ana, I.G.H., Suárez-Fernández, M.B., PérezSánchez, R., Gómez-Sánchez, M.Á., MoralesCorts, M.R. 2021. 'Compost Tea Induces Growth and Resistance against Rhizoctonia solani and Phytophthora capsici in Pepper', Agronomy, $11, \quad 781$. https://doi.org/10.3390/agronomy11040781.

Andre, C.M., Ghislain, M., Bertin, P., Oufir, M., M.D.R. Herrera, Hoffmann, L., Hausman, J.F., Larondelle, Y., Evers, D. 2007. 'Andean potato cultivars (Solanum tuberosum L.) as a source of antioxidant and mineral micronutrients', J. Agric. Food Chem. 55, pp. 366-378.
AOAC, 1985. 'Official methods of analysis' Association of Official Analytical Chemists Washington, D.C. pp. 490-510.

Arancon, N.Q., Edwards, C.A., Dick, R., Dick, L. 2007. 'Vermicompost tea production and plant growth impacts', Biocycle 48, pp. 51-52.

Battacharyya, R.N., Pati, B.R., 2000. 'Growth behaviour and Indole Acetic Acid (IAA) production by a Rhizobium isolated from root nodules of Alyscarpusvaginalis DC', Acta Microbiol. Immunol. Hung, 47(1), pp. 41-51.

Benítez, T., Rincón, A.M., Limón, M.C., Codón, A.C. 2004. 'Biocontrol mechanisms of Trichoderma strains', International Microbiology, 7, pp. 249-260.

Benito, M., Masaguer, A., De Antonio, R., Moliner, A. 2005. 'Use of pruning waste compost as a component in soilless growing media', Bioresource Technology 96, pp. 597603.

Chapman, H.D. and Pratt, P.F. 1978. 'Methods of analysis for soils', Plant and Water Univ. California. Div. Agric. Sci., 16-38.

Chen, B., Mellenthin, W.M., 1981. 'Effect of harvest data on ripening capacity and postharvest life of Anjou pears', J. Amer. Soc. Hort. Sci., 106, pp. 38-42.

Djaman, K., Sanogo, S., Koudahe, K., Allen, S., Saibou, A., Essah, S., 2021. 'Characteristics of Organically Grown Compared to Conventionally Grown Potato and the Processed Products', Sustainability. 13(6289), pp. 1-27. https://www.mdpi.com/journal/sustainability .

Egwunatum, A., Lane, S. 2009. 'Effects of compost age on the suppression of Armillaria mellea with green waste compost teas', Compost Science \& Utilization 17, pp. 237240.

El-Dissoky, R.A. 2008. 'Studies on the use efficiency of potassium and organic fertilizers on potatoes and its role in improving soil properties', Ph. D. Thesis. Fac. of Agric., Mansoura, Univ., Egypt. 
El-Shazly, M.M. 2008. 'Potassic, organic and biofertilization of potatoes under alluvial soil conditions', Ph.D. Thesis. Fac. of Agric., Mansoura, Univ., Egypt.

El-Tantawy, I.M., El-Ghamry, A.M. and Habib A.H. 2009. 'Effect of chicken manure and manure compost tea on potato yield and soil fertility. Journal of Agricultural Science, Mansoura Univ., 34(1), pp, 659-668.

El-Wehedy, A.M.A. 2008. 'Evaluation of some organic wastes and their potential for nutrient supply to plants in an alluvial soil', Ph.D. Thesis. Fac. of Agric., Mansoura, Univ., Egypt.

El-Yazid, A.A., Abou-Ali, H.A., Mady, M.A., Moussa, S.A.M. 2007.'Enhancing growth, productivity and quality of squash plants by using phosphate dissolving microorganisms (bio phosphor) combined with boron foliar spray', Res. J. Agric. Biol. Sci.,3(4), pp. 274286.

Emmanuel, M., Maerere, A.P. 2018. 'Growth and yield performance of watermelon during dry and wet seasons under tropical conditions', International Journal of Vegetable Science, DOI: 10.1080/19315260. 1439554.

FAOSTAT. (2014). 'Food and Agricultural commodities production'. Available form: http://faostat3.fao.org. [Accessed : 2014-1023].

Fernandez-Luqueno, F., Reyes-Varela, V., Martinez-Suarez, C., Salomon-Hernandez, G., Yanez-Meneses, J. 2010. 'Effect of different nitrogen sources on plant characteristics and yield of common bean (Phaseolus vulgaris, L.)'. Bioresource Technology101, pp. 396403, www.elsevier.com/loate/biortech.

FlieBbach, A., Oberholzer, H.R., Gunst, L., Mader, P. 2006. 'Soil organic matter biological soil quality indicators after 21 years of organic and Conventional farming', Agric., Ecosystems and Environment 118, pp, 273-284.

Ibrahim, H.A.K. 2018. 'Impact of compost tea in controlling chocolate leaf spot disease and soil micro-organisms' density on faba bean (Vicia faba, L.)', Egyptian J. Desert Res., 68(1), pp. 89-116.

Ingham, E.R. 2000. 'Brewing compost tea', Kitchen Gard, 29, pp. 16-19.

Jackson, M. L. 1967. 'Soil chemical analysis', Prentic Hall, Inc., Engle wood cliff., USA.

Jeffries, P., Gianinazzi, S., Perotto, S., Turnau, K., Barea, J.M. 2003. 'The contribution of arbuscular mycorrhizal fungi in sustainable maintenance of plant health and soil fertility', Biol. Fertil. Soils 37: 116.

Jeyabal, A., Kupuswamy, G. 2001. 'Recycling of organic wastes for the production of vermicompost and its response in rice legume cropping system and soil fertility', European Journal of Agronomy, 15, pp. 153-170.

Kandil, A.A., Attia, A.N., Badawi, M., Sharief, A.E., Abido, A.H. 2011. 'Effect of water stress and fertilization with inorganic nitrogen and organic chicken manure on yield and yield components of potato', Australian J. of Basic and Applied Science. 5(9), pp. 997- 1005.

Landon, J.R. 1991. 'Booker tropical soil manual: A handbook for soil survey and agricultural and evaluation in the tropics and sub-tropics', Longman Scientific and Technical, Essex, New York. pp. 474.

Larkin, R.P., Griffin, T.S., Honeycutt, C.W. 2010. 'Rotation and cover crop effects on soil-borne potato diseases, tuber yield, and soil microbial communities', Plant Dis 94, pp. 1491-1502. doi:10.1094/PDIS-03-100172.

Lowther, J.R. 1980. Use of single $\mathrm{H}_{2} \mathrm{SO}_{4}-\mathrm{H}_{2} \mathrm{O}_{2}$ disgest for the analysis of Pinus radiata, needles. 'Commun. Soil Sci.' Plant Anal., 11, pp. $175-188$.

Malik, C.P., Singh, M.B. 1980. Plant enzymology and histo-enzymology.

Mandic, L., Djukiæ, D., Beatovic, I., Jovovic, Z., Pesakovic, M., Stevovic, V. 2011. 'Effect of different fertilizers on the microbial activity and productivity of soil under potato 
cultivation', African Journal of Biotechnology. 10 (36), pp. 6954-6960.

Marquard, R.D. and Tipton, J.L. 1987. 'Relationship between extractable chlorophyll and an in situ method to estimate leaf greenness'. Hort. Science, 22 (6).

Marta, B., Ferrarini, A., Visioli, G. 2021. 'Improvement of Soil Microbial Diversity through Sustainable Agricultural Practices and Its Evaluation by -Omics Approaches: A Perspective for the Environment, Food Quality and Human Safety', Microorganisms, 9, 1400. https://doi.org/10.3390/microorganisms 9071400 .

Martin, C.C.S. 2014. 'Potential of compost tea for suppressing plant diseases', CAB Reviews 9, pp. 1-38.

Mengesha, W.K., Gill, W.M., Powell, S.M., Evans, K.J., Barry, K.M. 2017. 'A study of selected factors affecting efficiency of compost tea against several fungal pathogens of potato', Journal of Applied Microbiology. 123, pp. 732-747. ISSN: 1364- 5072,

Meunchang, S., Panichsakpatana S., Weaver, R.W. 2006. 'Tomato growth in soil amended with sugar mill by products compost'. Plant and Soil, 280, pp. 171-176.

Morales-Corts, M.R., Pérez-Sánchez, R., GómezSánchez, M.Á. 2018. 'Efficiency of garden waste compost teas on tomato growth and its suppressiveness against soilborne pathogens', Sci. Agric., 75(5), pp. 400-409.

Moretti, S.M.L., Bertoncini, I.B., Abreu-Junior, C.H. 2015. 'Composting sewage sludge with green waste from tree pruning', Scientia Agricola 72, pp. 432-439.

Page, A.L., Miller, R.H., Keeney, D.R. 1982. 'Methods of Soil Analysis', Part 2 - Chemical and Microbiological Properties, $2^{\text {nd }}$ Edition. Agronomy Society of America. Madison, WI.

Pane, C., Celano, G., Villecco, D., Zaccardelli, M. 2012. 'Control of Botrytis cinerea, Alternaria alternata and Pyrenochaeta lycopersici on tomato with whey compost-tea applications', Crop Protection 38, pp. 80-86.

Pant, A.P., Radovich, T.J., Hue, N.V., Paull, R.E. 2012. 'Biochemical properties of compost tea associated with compost quality and effects on pak choi growth', Scientia Horticulturae 148, pp. 138- 146 .

Papavizas, G.C. 1985. 'Trichoderma and Gliocladium: Biology, ecology and potential for biocontrol', Ann. Rev. Phytopathol., 23, pp. 23-54.

Philip, R., Warman, A., Vernon Rodd, P. H. 2011. 'The effect of MSW compost and fertilizer in extractable soil elements, tuber yield, and elemental concentrations in the plant tissue of potato', Potato Research, 54, pp. 1-11.

Reeve, J.R., Carpenter-Boggs, L., Reganold, J.P., York, A.L., Brinton, W.F. 2010. 'Influence of biodynamic preparations on compost development and resultant compost extracts on wheat seedling growth'. Bioresource Technology 101, pp. 5658-5666.

Reino, J.L., Guerrero, R.F., Hernández-Galán, R., Collado, I.G. 2008. 'Secondary metabolites from species of the biocontrol agent Trichoderma'. Phytochemistry Review, 7, pp. $89-123$.

Robert, P., Larkin, T., Griffin, S., Wayne Honeycutt, C. 2012. 'Rotation and cover crop effects on soil borne potato diseases, tuber yield and soil microbial communities', Agricultural Research Service, New England Plant, Soil and Water Laboratory. 94(12), pp. 1491- 1502.

Rokhzadi, A., Asgharzadeh, A., Darvish, F., NourMohammadi, G., Majidi, E. 2004. 'Influence of plant growth promoting rhizobacteria on dry matter accumulation and yield of chickpea', American-Eurasian Journal of Agricultural and Environmental Sciences, 3(2), pp. 253-257.

Ros, M., Hernandez, M.T., Garcia, C., Bernal, A., Pascual, J.A. 2005. 'Biopesticide effect of green compost against fusarium wilt on melon 
plants', Journal of Applied Microbiology 98, pp. 845- 854 .

Scheuerell, S.J., Mahaffee, W.F. 2004. 'Compost tea as an container medium drench for suppressing seedling damping-off caused by Pythium ultimum', Phytopathology, 94, pp. 1156- 1163.

Schonbeck, F., Dehne, H.W. 1986. 'Use of microbial metabolites inducing resistance against plant pathogens. In., Microbiology of phyllosphere, Fokkema, N.J. and J. Van den Heuvel (Eds.), Cambridge University Press, Cambridge, MA. pp. 361-375.

Setiyo, Y., Gunam, I.B.W., Gunadnya, I.B.P., Susrusa, K.B., Permana, D.G.M., Lriani, I.G.A. 2016. 'Improving soil physical and chemical characteristic on potatoes (Solanum tuberosum L.) cultivation by implementation of LEISA system', Agriculture and Agricultural Science Procedia. 9, pp. 325-331.

Shaban, H., Fazeli-Nasab, B., Alahyari, H., lizadeh, G., Shahpesandi, S. 2015. An Overview of the Benefits of Compost tea on Plant and Soil Structure. Advances in Bioresearch. 6 (1), pp. 154-158. 0976-4585; Online ISSN 2277-1573, http://www.soeagra.com/abr.html
Shaheen, A.M., Fatma A. Rizk, Abd El-Samad, E.H., Mahmoud, S.H., Dina M. Salama. 2018. 'Chicken Manure Tea and Effective Microorganisms Enhanced Growth and Productivity of Common Bean Plants', Middle East Journal of Agriculture. 7(4), pp. 1419- 1430, ISSN 2077-4605.

Shoresh, M., Harman, G.E., Mastouri, F. 2010. 'Induced systemic resistance and plant responses to fungal biocontrol agents', Аппи. Rev. Phytopathol., 48, pp. 21-43.

Soltanpour, P.N. 1985.'Use of ammonium bicarbonate DTPA soil tests to evaluate elemental availability and toxicity'. Commun. Sci. Plant. Analysis, pp. 323-338.

Steel, R.G.D., Torrie, J.H. 1980. 'Principles and Procedures of Statistics', $2^{\text {nd }}$ Edition. McGrow. Hill, New York.

Vinale, F., Sivasithamparam, K., Ghisalberti, E.L., Marra, R., Woo, S.L., Lorito, M. 2008a. 'Trichoderma-plant-pathogen interactions', Soil Biology and Biochemistry, 40, pp. 1-10.

Yadava, U.L. 1985. 'Arapid and non destructive methods to determine chlorophyll intact leaves'. Hort. Science, 21, pp. 1449- 1450. 